\title{
Doop as die deur tot die nagmaal: 'n Perspektief op kinderdeelname aan die \\ nagmaal
}

J Otto

Newlands, Johannesburg

\begin{abstract}
Baptism as the gateway to the Eucharist: a perspective on child participation in the Eucharist.

This article investigates the relationship between Baptism and the Eucharist and argues that baptism forms the gateway to meaningfully participating in the Eucharist. Children are excluded from participation in the Eucharist because the act of being baptised passes children's comprehension. It is argued that the baptism of a person has to be appropriated for the person to be able to meaningfully participate in the Lord's supper. Confession of faith in public is such an act of appropriation.
\end{abstract}

\section{INLEIDING}

Daar gaan aanvanklik in hierdie stuk gebruik gemaak word van die term "kindernagmaal", aangesien dit die term is wat gebruik word in die debat rakende die saak. Wat eintlik ter sprake is, is die oopstel van die Nagmaal aan alle persone ongeag hulle ouderdom of lidmaat- en doopstatus. Dit moet duidelik gestel word dat dit nie moontlik is om die kindernagmaal in isolasie te behandel nie, aangesien dit een van die twee sakramente van die Reformatoriese kerk is. Om enige een van die twee te verstaan is dit belangrik om die verwantskap tussen die twee sakramente te verstaan en elkeen se eie betekenis afsonderlik onder oë te neem. Die aard en betekenis van elke kerklike handeling verskil van die volgende, en elkeen moet in sy uniekheid raakgesien word, terwyl die lyne van ooreenkoms ook in ag geneem moet word. Juis die feit dat hierdie twee handelinge saam verstaan word, beteken dat die innerlike bande tussen die twee raakgesien moet word. Die verstaan van die een het ' $n$ impak op die verstaan van die ander. 
Die oortuiging wat in hierdie stuk gehuldig word is dat die sleutel tot die regte verstaan van die moontlikheid van kindernagmaal gevind moet word in ' $n$ bepaalde verstaan van die doop. Die saak moet eintlik nog skerper gestel word. doop en Nagmaal as sakramente is nie op dieselfde vlak nie en dit is die tese van hierdie stuk dat die primêre handeling die doop is. Die doop het in sy volle betekenis groter belang en ' $n$ langer werking, in so mate dat die doop die deur tot die Nagmaal is. Hierdie tese dien as basis vir ' $n$ nuwe benadering tot die verstaan van en die uitnodiging tot die Nagmaal. Dit kan uit hierdie tese afgelei word dat sekere sake rakende lidmaatskap en opsig en tug 'n nuwe benadering verg.

Teen hierdie agtergrond kan dit gestel word dat die vraagstelling na die regverdigbaarheid van die kindernagmaal misplaas is. Die regte verstaan van die sakramentale aard van die doop maak dat die vraag eintlik moet verwys na die deelname aan die Nagmaal deur ongedooptes en onkundiges. Die vraag is na die absolute oopstelling van die Nagmaal aan mense wat nie gedoop is of belydenis afgelê het of gekatkiseer is nie, en saarn met hulle mense wat nie die betekenis van die doop, ook hulle eie doop, verstaan nie en daarom ook onkundig is betreffende die Nagmaal.

In wat volg, sal daar eers duidelikheid gekry moet word oor die aard van die sakramente. Daarna sal die doop en die volie betekenis van die doop uitgestip word. Die impak van die doop op sake soos lidmaatskap moet uitgepluis word. Die gevolge van die suigelingdoop en die gevaar van sakramentalisme sal hanteer word alvorens die Nagmaal as die maaltyd van 'n geloofsgemeenskap behandel sal word.

\section{SAKRAMENTE}

Die doop en die nagmaal is die twee sakramente wat in Reformatoriese tradisie gehandhaaf word, al het sommige Reformatore die bieg ook 'n minimale rol toegeken (Rohls 1989:141). Dit is egter nodig om aan te dui wat ons bedoel met die term sakrament, en waarom ons hierdie twee handelinge as sodanig beskou. 'n Oorsig oor die geskiedenis sal dit duidelik maak dat daar nog nooit 'n eenduidige definisie van die term beskikbaar was nie. Die belangrikste wat egter na vore tree, is dat die sakramente (Reformatories gesproke) gesien word as daardie kerklike handelinge wat hulle ontstaan terugvind in Jesus self waarin woord en teken op 'n unieke manier die ontvanger se geloof versterk. 
Die sakramente bestaan ook uit die saamgebruik van die woord en die teken. Die een kan nie sonder die ander verstaan word nie. Deelname en of ontvang van die sakramente is reeds deur Luther gesien as 'n wesenskenmerk van Christenwees (vgl Ott 1981:466).

Aanvanklik was daar verskeie heilige handelinge, gebeurtenisse en tekens (vgl Calvyn IV, xIv.18.20) wat naas die doop en die Nagmaal gestaan het, maar die doop en Nagmaal het uitgestaan as geheimenisse (mysterion in Grieks). Van die vroeë handelinge word nie eens meer deur die Rooms-Katolieke Kerk as sakramente gesien nie. Die Latynse term (sacramentum) het egter gou die omgangswoord geword om hierdie heilige handelinge te beskryf, en Tertullianus gebruik reeds die term asof dit 'n vanselfsprekende keuse is (Lohse 1989:134). Dit was egter Augustinus wat die term vir die eerste keer gedefiniëer het as die element wat by die woord gevoeg word, wat lei tot die sakrament as 'n soort van sigbare woord (Lohse 1989:137).

Die Heidelbergse Kategismus, Sondag 25 vraag 66-7 (NHKA 1997:149) definieer sakramente as sigbare en heilige tekens wat deur God ingestel is. Vraag 68 stel dit weer duidelik dat die twee sakramente deur Christus ingestel is. Daaruit kan afgelei word dat Christus die sakramente met Goddelike gesag ingestel het. Dit is ingestel om die beloftes van die evangelie meer verstaanbaar te maak en te bevestig. Die beloftes waarna verwys word, is die vergifnis van sondes, en die geskenk van die ewige lewe. Dit is genadige geskenke wat God gegee het deur die kruisdood en opstanding van Jesus Christus (Gal 3:27-29). Beide sakramente roep die mens tot geloof en wys die mens daarop dat sy saligheid slegs gegrond kan word in die offer an die kruis. Die Heilige Gees oortuig gelowiges van hierdie saligheid wat Christus bewerkstellig het.

Uit die NGB, Artikel 33 (NHKA 1997:129) is dit duidelik dat die sakramente sonder Jesus Christus geen betekenis sou hê nie. Die sakramente is wel uiterlike sigbare tekens, maar dit bevestig 'n inwendige en onsigbare saak. God voeg by die Woord van die evangelie sakramente om aan die mens se uitwendige sintuie deur die krag van die Heilige Gees die innerlike werking te kenne te gee. Sonder begrip van die proses is sodanige handeling met ander woorde sinneloos.

Calvyn (IV, xiv.1) se definisie laat die klem lê op die uitwendigheid van die teken wat deur God gegee is om die mens se swak geloof te versterk. Opvallend is dat die Nagmaal ook gesien word as 'n teken wat getuig van vroomheid voor God, engele en 
medemense. Dit is duidelik dat die getuieniskarakter van deelname aan die Nagmaal nie uitgelaat word nie. Calvyn (IV, xIV.14) is dit met Augustinus eens dat die onsigbare heiliging van die mens kan geskied sonder die sigbare tekens, en dat sigbare tekens gegee kan word sonder die onsigbare heiliging van die ontvanger. Vroeg reeds is daar met ander woorde die oortuiging dat sakramente nie 'n geheime onafhanklike werking (ex opere operato) het nie.

Daarmee saam kan die sakramente gesien word as sigbare/tasbare verkondiging van die evangelie. Beide doop en Nagmaal is liturgiese handelinge wat binne die ruimte van die kerk en erediens werklikheid word. Sover dit Skrifbewyse aangaan, word dit gou duidelik dat die kerk van oortuiging is dat die twee sakramente hulle beslag in Jesus self terugvind (vgl Calvyn IV, xIv.17.18). Tradisioneel is hierdie aanname gebaseer op teksgedeeltes soos Matteus 26:26-30; 28:19, Lukas 22:14-23; Markus 14:22-26 en I Korintiërs 11:23-25. Dit val nie binne die raamwerk van hierdie artikel om diepgaande eksegese van hierdie gedeeltes te doen nie. Daar is egter voldoende kommentare beskikbaar om aan te toon dat hierdie aanname van die kerk (teksimmanent) op Skriftuurlike gronde rus (vgl McNeile 1980:348, 434, 435; Grosheide 1980:268-272; Geldenhuys 1979:550-565).

Die Skrifgedeeltes verwys nie net na die dele in die Bybel waar Jesus dit instel of as opdrag gee nie, maar in die besonder daarna dat, Jesus die inhoud van die sakramente is (vgl Calvyn IV, xIv.16). Daar kan wel vanuit 'n histories-kritiese perspektief gevra word na die geldigheid van 'n standpunt wat doop en Nagmaal in Jesus se eie opdragte terugvind. Metodologies moet die antwoord wees dat geen wetenskaplike benadering die ondersoeker kan terugneem na 'n tyd voor Golgota en die opstanding nie. Rekonstruksies sal derhalwe gebaseer word op veronderstellings en vooroordele. Daar word hier gekies vir 'n teksimmanente hantering van die bronne met al die veronderstellings wat daarmee saamgaan. Die belangrike punt is dat Jesus inhoudelik substansie en betekenis gee aan die twee sakramente.

Daarmee saam word 'n spesifieke werking deur die Heilige Gees veronderstel tydens die handelinge rondom die sakramente. Sonder die teenwoordigheid en werking van die Gees word sakramente leë handelinge (vgl Calvyn IV, xIv.9). Calvyn (IV, xIV.11) vergelyk die werk van die Gees met die gelykenis van die saaier. Waar saad op 
onbewerkte grond val, groei dit nie, maar bewerk deur die Gees, groei die saad van geloof wat deur die sakramente geplant word. Die simboliek as tema is ook eie aan sakramente as kultiese handelinge. Sakramente is simboliese handelinge wat slegs deur die gelowige deelnemer verstaan en toegeëien kan word.

Beide handelinge vind binne die liturgiese ruimte plaas en roep Jesus se versoeningsdaad aan die kruis in herinnering. Die doop en die Nagmaal gryp terug na die versoenende dood van Jesus en die verlossende opstanding. Daarmee saam gryp beide handelinge vooruit, na die einde van tyd, wanneer die mens wat verlos is, ewig saam met God sal wees. Doop en nagmaal betrek die enkeling en die gemeenskap. Die doop betrek die enkeling en wys op die geloofsverbintenis van die enkeling. Hierdie geloofsverbintenis verwys na 'n eie bekering, asook die deelname aan die verbond. Aan die ander kant is die Nagmaal as gemeenskapsmaal gemik op die geloof van die hele geloofsgemeenskap. Die groep gedooptes saam word gevoed en onderhou deur die een maaltyd.

Dit moet egter duidelik gestel word dat die begrip "sakramente" twee orde gebruik is. Dit is 'n begrip wat gebruik word om die intrinsieke waarde van die doop en Nagmaal aan te dui. Doop en Nagmaal het hulle innerlike waarde en toepassing gehad lank voordat teoloë 'n naam aan die handelinge toegedig het. Die term sakrament is met ander woorde gebruik om ' $\mathrm{n}$ toestand en werking wat reeds bestaan het, te beskryf. Doop en Nagmaal is in eie reg sakramente, nie effektiewe heilsmiddele omdat hulle "sakramente" genoem word nie. Beide sakramente wys die mens heen na Jesus se heilshandelinge. Hierdie tekens wat die mens wys op Jesus se offerdood, vorm 'n eenheid. Beide is sigbare tekens wat die mens rig op Jesus. Beide handelinge gaan gepaard met woordverkondiging.

Dit moet egter ook duidelik gestel word dat daar ook baie duidelike verskille is tussen die twee sakramente wat betref oorsprong, inhoud, frekwensie en betekenis. Indien dit nie die geval was nie, sou die debat binne oomblikke na een van twee kante geswaai het, óf grootdoop en Nagmaal net aan volwassenes, óf suigelingdoop en Nagmaal aan suigelinge.

In wat volg, sal daar net gekyk word na sekere eienskappe wat blyk aspekte van die wese van die sakramente te wees, veral sover dit die saak onder bespreking raak. Om op te som: die sakramente is kerklike handelinge wat meestal in die erediens bedien word op 
'n sigbare wyse, en hulle ontstaan terugvoer na 'n handeling en/of opdrag deur Jesus self. Hulle het ook 'n gemeenskaplike grond en inhoud, naamlik die verlossende lewe, lyding, sterwe en opstanding van Jesus.

\section{DOOP}

Dit is duidelik dat die kerk van vroeg af mense geroep het tot boetedoening en geloof, en mense wat hieraan gehoor gegee het, gedoop het. Hierdie doop was ook in opdrag van Jesus. Uit die Skrif is dit duidelik dat die doop 'n opdrag van die opgestane Heer is (Matt 28:19), en nie in navolging van die voor-Pase Jesus is nie. By die voor-Pase Jesus word bedoel Jesus voordat Hy na sy Goddelikheid bekend geword het by die opstanding uit die dood. Die doop is 'n teken van inwyding waardeur die mens in die kerk opgeneem word omdat die gedoopte in Christus ingewy word, en as kind van God gereken word (Calvyn IV, xv.1). Deur die teken en die woordverkondiging word die dopeling gereinig en aan God gewy om saam met die bruidegom te kan wees (Ef 5:26). Dit is ook duidelik dat Jesus nie self gedoop het nie, al het sy dissipels gedoop ( $\mathrm{vgl} \mathrm{Joh} \mathrm{4).}$

Die sakramente het 'n voorgeskiedenis van ooreenkomste met vorige sakramentele handelinge waarvan daar kennis geneem moet word (Rohls 1987:227), ook wat betref die onderskeid tussen ander vorme van doop en die doop as sakrament. Die eerste voorbeeld van doop kan ons, aldus Schlink (1985:479), terugvind in die Ou-Testamentiese wet van reiniging deur met water te was en te besprenkel. By die profete kry die heiliging van die volk 'n toekomstige karakter wat die verlede wegwas en die volk vir die toekoms reinig (vgl Es 36:25ev). In die na-eksiliese tydperk het reiniging 'n groter rol begin speel. Die doel daarmee was om onreinheid weg te was, nie om vergewing van sondes te bewerkstellig nie. Dit het dus seremoniële reinheid aangedui. Daar is ook sprake van 'n proselietedoop. Kenmerkend van hierdie afwassing was die feit dat dit iets is wat die mense aan hulleself gedoen het.

In hierdie milieu van selfreiniging kom Johannes die Doper na vore met 'n nuwe doop. Hy roep tot boetedoening, verkondig die oordeel van God en profeteer die uitstorting van die Heilige Gees. Sy doop roep boetedoening op, en is nie die gevolg van boetedoening nie. Hierdie trinitêre tema word in Jesus se doop gehandhaaf (Pannenberg 1989:239). Daar is ook ' $n$ duidelike eskatologiese dimensie in sy benadering tot die doop 
aan te dui. Sy doop is uniek in die sin dat hy mense doop, en nie mense daartoe roep om hulleself te doop nie. Geloof en bekering gaan egter nie hand aan hand nie. Sy doop is ook nie herhaalbaar nie, maar het eskatologiese geldigheid. Jesus val ook by hierdie patroon van Johannes in deur toe te laat dat Johannes Hom doop. By die doop van Jesus bereik Johannes se doop egter sy eindpunt en vervulling wanneer die Heilige Gees op Jesus uitgestort word. Dit waarna Johannes uitgesien het, word werklikheid wanneer hy Jesus doop. Deur Hom deur Johannes te laat doop, tree Jesus in die gemeenskap in en begin Hy iets wat Hy voleindig met die Paasgebeure. Deur die doop bevestig Jesus sy solidariteit met die mensdom tot op die kruis van Golgota. Dit is ook juis hierdie dood aan die kruis wat die grond vir die doop is ( $\mathrm{vgl}$ Rom 6).

Deur in die naam Jesus se naam te doop, word die Christelike doop onderskei van die proselietedoop of die doop van Johannes. Bekering en geloof was direk gekoppel aan die doop (Pannenberg 1989:245). Johannes se oproep tot bekering was gebaseer op die feit dat beroep en bekering die laaste kans was om van God se oordeel te ontsnap, terwyl Jesus se doop en oproep tot bekering sy rede teruggevind het in die nuwe tydperk van genade wat voorhande was (Pannenberg 1989:245). Jesus het die nuwe era ingelei waarin elke dopeling die Heilige Gees ontvang, op spoor van Jesus se eie doop toe die Heilige Gees op hom uitgestort is. In die doop gaan dit dan nie om die doop of die dopeling nie, maar om dit wat God aan die dopeling doen. Wat die uitwerking van die doop betref, kan daar op ' $n$ veelheid gewys word: sondevergifnis, heiliging en regverdiging, afwassing van sonde, reiniging van die hart van bose denke, sterwe en begrafnis en opstanding saam met Jesus, en vele meer. Met die doop is dit dan ook so dat die handeling met water en die uitspreek van die Christus naam onskeibaar is. Dit kom daarop neer dat daar nie net vergifnis van sonde plaasvind nie, maar dat die mens van die dwang van die sonde bevry word. Die koppeling met Jesus se naam dui op die band wat daar geskep word tussen dopeling en Christus.

Met die doop word daar met ander woorde nie 'n ander heilsdaad voltrek as dit wat aan die kruis gebeur het nie. Die heilsdaad word net persoonlik opgeneem. Die heilsdaad aan die kruis is voorwaarde tot die doop. Met die doop word die objektiewe heil van Jesus se sterwe en opstanding omskep tot die subjektiewe heil van die persoon wat die teken van die doop ontvang. Die doop is nie 'n nuwe heilsdaad nie, dit is net die 
geleentheid waarby die ontvanger deel word van die heilsdaad op Golgota. So word die kruisgebeure in die hede ingetrek.

Soos gewone geboorte, moet ons van die doop ook stel dat dit 'n permanente effek het (Pannenberg 1998:239). Net soos jy nie 'n tweede keer gebore kan word nie (vra maar vir Nikodemus), net so kan die wedergeboorte van die doop net eenmaal plaasvind. By die doop word die dopeling in verhouding gebring met Jesus en daarom met die Drie-Enige God. Van vroeg af het die Christene doop gekoppel aan die vergifnis van sondes aangesien die doop mense laat deel in die vrugte van Jesus se dood en opstanding. Die doop wys die mens op hierdie werklikheid. Op sigself kan die doop nie hierdie heil bewerk nie, die doop is slegs heenwysing, simbool van dit wat God bewerk het.

Daarmee saam beteken dit dat die mens deel kry aan die eskatologiese geskenk van die Gees. Die doop beteken daarom dat die dopeling deel aan die sterwe en opstanding van Jesus. Dit geskied op so 'n wyse dat die doop die mens vooruitwys na sy eie dood in die koppeling met die dood van Jesus. Daardeur word die mens verseker dat ook sy toekoms na die dood gekoppel word aan Jesus se bestaan na sy dood. Hoofsaaklik beteken dit dat die Christen doop in verband bring met sondevergifnis, die versoenende effek van die kruisdood en die eskatologiese geskenk van die Heilige Gees (vgl Pannenberg 1989:240). Die doop beteken dat die gelowige deel in die lotgevalle van Jesus in terme van nie net dood nie, maar ook die opstanding. Die doop kan nooit hierdie saligheid bewerk nie, maar bloot die mens daarheen wys. Die toekoms van 'n eie dood vind balans in die deelname van die dopeling in die lewe na die dood, saam met Jesus. Jesus se plaasvervangende lewe en sterwe word deur die doop so aan die mens toegewys dat dit nie nodig is vir die mens om te ly en sterwe nie. Dit kan nog skerper gestel word. Net soos die geboorte eenmalig is en die mens aan sy eie sterflikheid hou, net so gaan die eenmalige doop van die veronderstelling uit dat hierdie verbintenis eenmalig is en die hele lewe van die gedoopte raak (Pannenberg 1989:242).

Die doop as ' $\mathrm{n}$ handeling wat aan die mens bedien word, dui daarop dat die mens geroep word om in geloof te reageer, of om dit wat aan die mens gedoen is, te aktualiseer, al gebeur dit te midde van tekortkominge en gebreke. Slegs deur geloof word dit wat aan die mens gedoen is, naamlik inlywing in die sterwe en opstanding van Jesus, geaktualiseer. Geloof bly egter gawe van die Gees. Die antisipasie van die eie dood van die 
dopeling koppel die doop aan die hele lewe van die dopeling totdat ook hierdie verwagting geaktualiseer word. Dit beteken net weer dat doop nie herhaal kan word nie aangesien die koppeling met die eie dood eenmaal vir altyd plaasvind. Die aktualisering van dit wat in die doop plaasgevind het, moet op meer as een vlak verder verduidelik word, veral aangesien dit die aard van die suigelingdoop raak. In die een handeling van doop word die nuwe Christelike lewe beslag gegee. Pannenberg (1989:252) stel dat die wese van die Christen deur die doop bepaal is, nie deur iets wat buite om of na die doop plaasgevind het nie. 'n Christen kan afdwaal, maar kan weer sy weg terug vind (kyk Gal 5:4). Doop is daar vir die res van die lewe van die gelowige as onverwyderbare vastigheid in die verlede, 'n vastigheid wat God se genade verbeeld (Pannenberg 1989: 246).

Doop en geloof gaan hand aan hand. Die geskiedenis dui egter daarop dat bevestiging en doop met tyd van mekaar geskei is (Pannenberg 1989:244), en dat geloofsbelydenis as 'n entiteit op sy eie gesien is. Hierdie was nie noodwendig 'n goeie verwikkeling nie, aangesien dit eerder as twee fases van dieselfde gebeurtenis gesien was en so gesien moet word. Doop is na twee rigtings die sakrament van geloof. Bekering vind sy hoogtepunt in die doop van die regverdige (Gal 6:3ev) aangesien doop die filiale verbintenis met Jesus bemiddel. Aan die ander kant word die betekenis van die doop deur geloof na vore gebring. Doop wys daarop dat die apostolêre werk van die kerk met geloof beantwoord word (Matt 28:19). Die betekenis van die doop word egter in geloof toegeëien en uitgeleef. Juis hierdie verbintenis het gemaak dat Barth oortuig was dat slegs 'n volwassene gedoop mag word. Indien ons doop slegs as 'n openbare belydenis van geloof en bekering na 'n lewe voor God sien, moet Barth gelyk gegee word. Die doop is egter nie menslike werking of verdienste nie, maar God se genadige handeling aan die sondaar. Die mens kan nie eens van sola fide 'n nuwe verdienste mak in die ontvang van hierdie sakrament nie.

Doop doen egter iets vir en aan alle mense, selfs die mense wat voor hulle doop tot bekering gekom het, iets wat hulle nie vir hulleself kan doen nie. Dit is die duidelike koppeling van die dopeling aan die eindbestemming van Jesus. Doop is nie 'n menslike handeling nie, dit is iets wat aan die mens gedoen word aangesien niemand hom- of haarself kan doop nie. Die belofte van die dopeling kan nie op dieselfde vlak staan as die genadedaad van God nie. Die dopeling aanvaar bloot die genadige werking van God se 
genadige werk. Mense word gedoop deur ander wat hulle op Goddelike magtiging beroep. Dit wil sê 'n mens word deur God self gedoop, al is dit iemand anders wat dit bedien. Dit is God self se werk. Pannenberg stel (1989:261) dit soos volg:

For to be baptized in the name of God is to be baptized not by others but by God himself, so that even though others administer it, it is truly God's own work. Baptism certainly does not bring salvation without faith. It relates always in some way to the faith of the baptized, but my faith does not make baptism - it receives it.

Geloof en doop is aan mekaar gekoppel: maar geloof maak nie die doop nie, dit ontvang slegs die doop. Doop mik na die geloof van die ontvanger, maar geloof kan nooit doop as verdienste of eie geregtigheid veronderstel nie, aangesien geloof doop net kan ontvang - en nie kan verdien nie. Die eie aard van die doop maak met ander woorde die doop van suigelinge moontlik. Pannenberg (1989:265) redeneer ten gunste van suigelingdoop deur te stel dat dit ten gunste van die suigelingdoop tel dat God se aanspraak op die lewe van die dopeling enige eie ervaring en pogings voorafgaan. Selfs die mense wat eers op 'n later stadium bewustelik hulle doop toeëien, kan daarin vrede vind dat God hulle hele lewe aanneem - van begin tot einde en dat hulle lanks reeds deelgenootskap met God in Jesus het.

Hierdie twee sake kan soos volg aan mekaar gekoppel word: die handeling van die doop aan die een kant en die gelowige toeëiening aan die ander kant. Doophandeling mak nie die saligheid effektief werksaam in die enkeling nie, dit roep tot geloof. Doop is daarom gemik op die geloof van die dopeling, maar veronderstel dit nie noodwendig nie aangesien geloof slegs doop kan ontvang. Wat God sê, bly staan, ongeag die mens se spesifieke stadium van denke of ontvanklikheid. Dit maak die doop van suigelinge moontlik. Dit beteken egter ook dat dit nie die einde van die doopgebeure kan wees nie, aangesien die latente geaktualiseer moet word. Doop en bekering, doop en selfaktualisering is keerkante van dieselfde munt. 
Die aktualisering van die doop kom tot uitdrukking in die geloofsbelydenis van die dopeling. By hierdie geleentheid eien die dopeling hom- of haarself die doopgebeure toe. Geloofsbelydenis is egter nie die einde van die doop nie, dit is die begin van ' $n$ lewe van toeëiening wat deur die doop begin is. Belydenis en doop gaan egter hand aan hand, en by geloofsbelydenis word dieselfde proses voltrek wat die volwasse dooplidmaat van die kerk deurgemaak het. So gesien, is die geloofsbelydenis die versterking en seën van dit wat reeds by die doop ontvang is. Doop en openbare belydenis hoort saam (vgl Pannenberg 1989:265; Weber 1983:612-613). Doop het toeëiening deur geloof nodig. Geloof het doop nodig. Die beloftes van deelname aan Christus se lyding, sterwe en opstanding word in die doop gegee. Doop is en bly God se werk wat vooruitwys op die mens se hele lewe. Die suigelingdoop word die jongmens se doop by belydenis van geloof, net so word die oumens se doop eweneens by belydenis van geloof 'n eie werklikheid. Die belangrike is nie die tydstip waarop dit gebeur nie, maar dat dit wel moet gebeur. Daar kan baie gedebatteer word oor die ouderdom van die persoon wat belydenis doen, maar by hierdie geleentheid aktualiseer die gelowige die geskenk van God in 'n eie lewe. In 'n sekere sin kan gestel word dat dit wat by die suigelingdoop gebeur het, by die belydenis voltrek word. Dit bevraagteken nie die lidmaatskap van die dopeling in die tussentyd nie, dit relativeer dit slegs. Daar moet gewaak word teen 'n streng temporele beredenering van die saak. $\mathrm{Al}$ verloop daar tyd tussen doop en aktualisering, beteken dit nie dat die twee los van mekaar gesien moet word nie. Die mens kom in die proses van kategese by die punt om te besef wat dit is wat God aan hom of haar gedoen het. By geloofsbelydenis gebeur daar dan nie iets nuuts of anders nie, dit wat by die doop gebeur het, vind net sy vervulling. Suigelingdoop noodsaak 'n latere belydenis en dit noodsaak op sy beurt kategese as die proses wat die dopeling die betekenis van die doop leer (Pannenberg 1989: 268). Dit beteken nie dat die doop ongeldig word indien die persoon nie die doop toeëien nie. God se genade kan nie aan menslike willekeur uitgelewer word nie.

Aktualisering as woord om die handeling van geloofsbelydenis te beskryf, kan vervang word met 'n woord soos toeëien. Die kern van die saak is dat die mens nie deur sy handeling van geloof bely, God se handeling by die doop afhandel nie, maar net die doop sy eie maak. Hierdie eie maak verwys na die mens se persoonlike besef van dit wat 
God gegee het in Christus. Deur 'n belydenis van geloof, gee die mens erkenning aan dit wat deur God aan hierdie mens gedoen is. Wanneer die mens die doop aktualiseer, is dit nie skielik 'n geval van die mens wat meer as God doen nie. Die mens is net besig om dit sy eie te mak en in die opsig (persoonlike toeëiening) die doop te finaliseer. Die mens se saligheid word egter nie in sy geloof gegrond nie, maar in sy doop. Geloofsinhoud en doop is God se werk, die mens is bloot dankbare ontvanger.

\section{NAGMAAL}

Die Nagmaal vind sy oorsprong terug by Jesus self wat op die vooraand van sy kruisiging dit ingestel het. Daar is tog 'n voorgeskiedenis wat genoem moet word. Die Nagmaal word duidelik gekoppel aan die pasgamaaltyd en die herinneringsmaal na aanleiding van die uittog uit Egipte (Schlink 1985:492). By die uittog en verbondsluiting by Sinai ontstaan 'n band tussen God en volk wat telkens bevraagteken word wanneer die volk in ongehoorsaamheid verval. Die verlossing van die volk is egter altyd 'n tema tydens die herinneringsmaal. Die tweede lyn van die Nagmaal kan teruggevind word in die vele maaltye wat Jesus gehad het met mense uit alle lae van die samelewing. Daar is egter 'n duidelike breuk tussen al hierdie sake en die viering van die maaltyd deur die vroeë Christene, en dit is die dood en opstanding van Jesus. Hierdie gebeure gee 'n radikaal nuwe betekenis en diepte aan alles wat dit vooraf gegaan het, selfs die instelling deur Jesus self.

Die maaltye van Jesus saam met mense wat Hom uitgenooi het, dui op Jesus se bereidheid om deelgenootskap met alle mense te hê. Dit het ook gedui op vergifnis van sonde sodat deelname aan die maaltyd gedui het op deelgenootskap met God en deelname in die toekomstige Koninkryk van God. Hierdie aspekte is deel van 'n geldige verstaan van die Nagmaal.

By die doop word ons deel van Christus en sy liggaam, en tydens Nagmaal word die deelgenootskap hernu en bevestig ooreenkomstig die instelling deur die Here Jesus self. Nagmaal is gelyk ook herinneringsmaal waartydens Jesus se opdrag, sy dood en opstanding in herinnering geroep word deur die aanwesiges. Tegelyk is die Nagmaal waarin die gelowiges die ware teenwoordigheid van Jesus deur bemiddeling van die Heilige Gees bely en ervaar (vgl Schlink 1985:490). Die Een wat teenwoordig is by die 
maaltyd, is dieselfde Een wat gesterf het en opgestaan het. Hierdie Een maak deelname aan die plaaslike gemeente se handelinge, die deelnemers van die ekklesia van alle plekke en tye.

Tydens die Nagmaal roep die gemeente Jesus se lewe in herinnering, en deur geloof eien hulle Jesus se teenwoordigheid toe deur die eet van brood en die drink van wyn. Nagmaal het 'n duidelike eskatologiese dimensie (vgl Pannenberg 1989:285). Die gemeente word in die hede getroos en na die heerlike toekoms saam met God gerig. Deelname is egter duidelik aan geloof gekoppel, die geloof wat deur die doop in die lewe geroep word.. Deelname aan die Nagmaal kan nie sonder gevolg wees nie (1 Kor 11:29), en daarom word deelname deur die aard van die Nagmaal beperk tot mense wat tot geloof gekom het. 1 Korintiërs 11:29 dui op deelname deur 'n persoon wat geen begrip het van die geloofsinhoud van wyn en brood nie. Slegs die gelowige eet die brood en drink van die wyn in die wete dat dit sakrament is van Jesus se offerdood. Dopelinge is deur hulle doop reeds gelowiges en daarom kan daar volgens Pannenberg (1989:292) geen beswaar wees teen deelname deur gelowige dopelinge nie.

Die gelowige dopeling is daardie persoon wat die gebeurtenis toegeëien het. Die kern van die saak is dat daar by die Nagmaal 'n aktiewe deelname is, terwyl die doop baie meer passief is. Doop word aan jou gedoen, jy staan op en neem deel aan die Nagmaal, by herhaling. Albei sakramente verbind die gelowige egter aan die kerk en skep die eenheid van gelowiges. Doop maak alle gelowiges 'n integrale deel van die kerk en hierdie eenheid word verteenwoordigend gevier by die Nagmaal (1 Kor 12:13).

Lidmaatskap is nie die voorwaarde tot Nagmaal nie. Die gedagte dat lidmaatskap dien as voorwaarde tot deelname moet vervang word met die gedagte dat die gedoopte persoon wat hierdie doop sy of haar eie gemaak het en verstaan, tot die Nagmaal toegelaat moet word. Dit beteken dat kategese nie gesien moet word as die proses van ' $n$ persoon 'n lidmaat maak nie. Dreyer (1999:563-586) het duidelik aangetoon dat doop lidmaatskap beteken. Kategese moet gesien word as die proses wat die persoon begelei om sy of haar doop en die Nagmaal te verstaan. Die kerk moet herbesin oor die kategeseprogram se doel en dit aanpas by die antwoorde wat uitkristalliseer. Kategese kan sekondêr lidmate voorberei vir diens in die kerk en lidmate die breë spektrum van sake aanleer, maar kategese moet lidmate leer wat die sin en betekenis van die doop en 
Nagmaal is. Die primêre taak van kategese is egter om die persoon te begelei tot begrip van dit wat God aan hom of haar gedoen het. Deelname aan die Nagmaal impliseer ' $n$ kennis van die implikasies van die Nagmaalshandelinge en 'n lewenswyse wat met hiermee ooreenstem. Pannenberg (1989:330) stel dissipelskap as voorwaarde tot deelname aan die Nagmaal. Hierdie dissipelskap impliseer 'n begeerte om deel van die kerk te wees en 'n kennis van die kerk en 'n verstaan van die eie doop.

Die klem op begripvolle deelname aan die Nagmaal word ondersteun deur 'n eksegese van 1 Korintiërs 12 . In die gedeelte word die mens geroep tot selfondersoek. Enige persoon wat nie kan onderskei dat dit die liggaam en bloed van Jesus is nie, drink en eet ' $n$ oordeel oor hom- of haarself. Dit is duidelik dat die Nagmaal meer as maar net 'n gemeenskapsmaaltyd is waartydens mense sosiaal saam verkeer. Nagmaal roep die mens tot verantwoordbare deelname. Dit beteken dat enige sprake van 'n kind van 4 of 5 jaar oud wat gaan aansit, verwerp kan word. Anders as met die doop kan die ouer nie instaan vir die begrip van die kind nie.

Die alternatief is dat die ouer 'n gesprek voor die Nagmaal met die kind voer, en dat die kind dan deelneem aan die Nagmaal. Ook hierdie moontlikheid moet afgewys word weens die sakramentele aard van die doop en Nagmaal. Die toeëiening van die doop kan nie in 'n ander ruimte as in die liturgiese ruimte plaasvind nie, aangesien die doop juis in die liturgiese ruimte bedien is. Die ouer kan en moet saam met die kategete werk om die kind te begelei tot die punt waar die kind verstaan wat die doop beteken, maar dit is binne die breër band van gelowiges wat hierdie toeëiening verwoord word en uitgeleef word. Dit hoef nie noodwendig die vorm van aanneem, belydenis en voorstelling te wees nie, maar die kerk het reeds hierdie gebruik en dit blyk sinvol om dit nou nie te gaan vervang nie, maar net weer die ware betekenis van hierdie handelinge aan lidmate duidelik te maak.

1 Korintiërs 12 lig ook 'n ander baie belangrike aspek uit, naamlik die oordeel van God. Hierdie oordeel is natuurlik nie ' $n$ oordeel om te verdoem en verwerp nie, dit is 'n oordeel om te red. Dit moet egter ook gestel word dat dit steeds God se oordeel is en daarom nie ligtelik opgeneem kan word nie. 'n Kind verstaan nie die doop nie, nog minder die Nagmaal. Kinders mag nie verhinder word om na God te gaan nie, want aan 
hulle en diesulkes behoort die Koninkryk van God, maar kinders moet daarvan beskerm word dat hulle onwetend hulleself die oordeel van God op die hals haal.

\section{DOOP EN NAGMAAL}

Die eerste onderskeid wat duidelik na vore kom, is dat die doop 'n opdrag van die opgestane Heer is, terwyl dit die Jesus is wat ly en op pad is na die kruis toe, wat die Nagmaal instel. Die tradisionele tyd van ontstaan verskil met ander woorde, voor Golgota en na Golgota. Beide sakramente ontvang egter hulle betekenis na die opstanding.

'n Tweede punt van verskil is die eskatologiese geldigheid van die doop in Jesus se naam. Daar word net een keer gedoop en dit het terugwerkende en vooruitskouende krag. Die doop raak die persoon se hele lewe, insluitend vooruitskouend sy eie dood. Die Nagmaal aan die ander kant is ' $n$ handeling van herhaling. By herhaling word die Nagmaalganger herinner aan Jesus se offer aan die kruis en word vergifnis en opstanding verkondig deur deelname aan die brood en wyn.

Daar moet ook meer gemaak word van die verskil tussen hede, verlede, en toekoms by doop en Nagmaal afsonderlik. Die doop gryp baie meer vorentoe, terwyl die Nagmaal meer geneig is om terug te kyk. Die doop gryp vooruit na die hele lewe van die dopeling terwyl die Nagmaal in die hede wil troos deur na die verlede en die belofte van die toekoms wil kyk.

Die doop is ' $n$ handeling wat aan 'n persoon toegedien word. In die Reformatoriese tradisie is dit anders met die Nagmaal. Die lidmaat neem self die brood en wyn en eet en drink dit: Alhoewel daar nie te veel van hierdie onderskeid gemaak moet word nie, is dit tog so dat daar 'n groter mate van deelname by die Nagmaal veronderstel word. Die aktiewe deelname van die lidmaat tydens Nagmaal is anders as die passiewe ontvangs tydens doop. Dit moet egter dadelik gestel word dat in beide gevalle dit God self is wat die heil bewerk. Nooit mag ons so verwaand wees om te stel dat ons God se genade kan afdwing, of dat deelname 'n magiese handeling veronderstel nie.

$\mathrm{Al}$ is beide handelinge duidelik sakramente, is daar duidelike verskille wat beteken dat die twee nie op gelyke vlak benader kan word nie. Deelname aan die Nagmaal impliseer dat die doop tot sy volle betekenis in die mens geaktualiseer het. Anders gestel, volle doop is voorwaarde tot Nagmaal. Die Nagmaal is die herinneringsgeleentheid wat 
in die eerste plek die gemeente opnuut konstitueer uit die teenwoordiges. Doop konstitueer die enkeling tot geroepene van God.

\section{SLOTOPMERKINGS}

Volle implementering van die doop beteken dat die dopeling die betekenis van die doop op die eie lewe van toepassing moes mak alvorens daar ruimte kan wees vir deelname aan die Nagmaal. Daar kan gepraat word oor die vervroeging van die geloofsbelydenis, maar alvorens dit nie gedoen is nie, kan daar nie sprake van kindernagmaal wees nie. In vorige eras is jongmense toegelaat tot die Nagmaal omdat hulle vroeg geloof bely het, maar dit was omdat die lewensverwagting laag was en meisies van 13 en 14 al kon trou (sodra hulle geslagsvolwasse geword het). Daarmee saam is daar min verskil tussen die Nagmaalsgesprek met die dopeling en die geloofsbelydenis. Albei gee erkenning aan die doopgebeurtenis en dui begrip en toeëiening aan. Kindernagmaal sonder 'n geskiedenis van doop sou dui op 'n ope uitnodiging selfs aan heidene. Dit sou die gemeenskapskarakter van die Nagmaal verloën.

Kindernagmaal moet los van enige emosies en humanistiese argumente binne die teologie beredeneer word. Myns insiens kan dit slegs geskied waar die doop geaktualiseer is, en dit is na geloofsbelydenis, op watter ouderdom dit ook al mag geskied. Geloofsbelydenis dui op die toeëiening van die doop, en nie die feit dat die persoon dan skielik 'n lidmaat is nie.

Die kern van die saak bly egter begripvolle deelname aan die Nagmaal deur die persoon wat gedoop is, en hierdie doop toegeëien/aktualiseer het. Indien hierdie saak nie begryp word nie, gaan die gesprek eerder oor die ouderdom van die kind/kleuter/suigeling wat Nagmaal ontvang en dan word die saak onmoontlik. Kinders/jongmense is op verskillende stadiums en ouderdomme voldoende ontwikkel om hulle doop en deelname aan die Nagmaal te verstaan, omdat elke persoon uniek is. Dit kan wees dat een kind geestelik ryp is op 12 en die volgende eers op 18. Die kerk het die taak om seker te maak die kind verstaan die Nagmaal en verstaan wat dit beteken dat hy of sy gedoop is. Dan kan daardie persoon tot die Nagmaal toegelaat word.

Dit bly die taak van die kerk om te verseker dat alles ordelik verloop en daarom kan hierdie verantwoordelikheid nie op die ouers afgewentel word nie. Die persoon wat 
sy doop sy eie gemaak het, kan begripvol deelneem aan die Nagmaal. Aandrang daarom dat kinders deelneem net omdat hulle kinders is, dui op onbegrip sover dit die betekenis van die doop en die Nagmaal betref.

\section{Literatuurverwysings}

Calvyn, J 1949. Institusie, Deel III, vertaling deur A Sizoo. Tweede druk. Delft: Meinema.

Dreyer, W A 1999. Die verband tussen doop en lidmaatskap van die kerk. HTS 55, 563586

Geldenhuys, N 1979 Commentary on the Gospel of Luke. Grand Rapids, MI: Eerdmans.

Grosheide, F W 1980 Commentary on the first epistle to the Corinthians. Grand Rapids, MI: Eerdmans.

McNeile, A H 1980 The Gospel According to St. Matthew. Grand Rapids, MI: Baker Book House

Nerduitsch Hervormde Kerk van Afrika 1997. Diensboek. Doornfontein: Kital.

Lohse, B 1989. A short history of Christian doctrine. Philadelphia: Fortress.

Ott, H 1981 Die Antwort des Glaubens. Berlin: Kreuz Verlag.

Pannenberg, W 1989. Systematic Theology, Volume 1. Grand Rapids, MI: Eerdmans.

Rohls, J 1987. Theologie reformierter Bekenntenisschriften. Göttingen: Vandenhoeck \& Ruprecht

Schlink, E 1985. Ökumenische Dogmatik: Grundzuge. Göttingen:Vandenhoeck \& Ruprecht.

Weber, O 1983. Foundations of dogmatics. Grand Rapids, MI: Eerdmans 